\title{
Escalating Disabilities Students' English Speaking Skill Through Sociodrama Method
}

\author{
Cicih Nuraeni, Aloysius RanggaAditya Nalendra, Yanti Rosalinah, Ibnu Subroto, Agus \\ Priadi \\ $\left\{\right.$ cicih@nusamandiri.ac.id ${ }^{1}$, aloysius2206@bsi.ac.id², yanti_rosalina@yahoo.com³ \\ ibnusubroto@stkipkusumanegara.ac.id ${ }^{4}$, agus.agp@bsi.ac.id $\left.{ }^{5}\right\}$ \\ Sastra Iggris, Sekolah Tinggi Ilmu Bahasa Asing Nusa Mandiri, Tangerang, Indonesia ${ }^{1,3}$, Manajemen \\ Informatika, AMIK BSI Tangerang, Tangerang, Indonesia ${ }^{2}$, Pendidikan Bahasa Inggris, STKIP \\ Kusumanegara, Jakarta, Indonesia ${ }^{4}$, Bahasa Inggris, Akademi Bahasa Asing BSI Jakarta, Jakarta, \\ Indonesia $^{5}$
}

\begin{abstract}
The aim of this research was to analyze the effectiveness of sociodrama method in escalating the disabilities students' speaking English skill at Special Need School (Sekolah Luar Biasa), South Jakarta, Indonesia. The method of the research was descriptive qualitative method which used 6 (six) orthopedically handicapped students as research objects. To collect the data, the researchers used observation, interview and documentation. The scale of assessment referred to norms referenced evaluation. The instruments were pre-test and post-test with 3 (three) criterion being assessed to the students namely vocabulary, fluency and comprehension. They were divided into 9 (nine) elements such as accuracy of word, understanding each word, word choice, intonation, pronunciation, speaking easily, understanding the meaning, diction, structure and grammar. The research found there was any escalation on vocabulary score about 26.16, fluency score lied on 30.50, comprehension score about 27.16 and the means of the score was 27.94. The research findings showed firstly, this sociodrama method was able to be applied either for physically normal students or disabilities students and the result was effective. Secondly, It could be inferred that the physically limitation did not make people difficult reach their achievement, it was proved by the escalation score from pre to post-test process.
\end{abstract}

Keywords: speaking, disabilities students, sociodrama.

\section{Introduction}

In the English teaching learning activities, there are four English language skills such as speaking, reading, writing, and listening [1]. One of the important skills which must be mastered is speaking. This priority makes the speaking skill is very important to be learned as a form to express a thought, feeling, idea, and concerning other people [2]. The reason why students should practice speaking in the class is to improve their ability in engaging grammar, diction or vocabulary, and fluency into a good idea [2]. This thing can also be conduct for disabilities students. There are three main reasons for getting students to speak in the classroom. Firstly, speaking activities provide rehearsal opportunities - chances to practice real-life speaking in the safety of the classroom. Secondly, speaking tasks in which students try to use any or all of the languages they know provide feedback for both teacher and 
students. Everyone can see how well they are doing: both how successful they are, and also what language problems they are experiencing.

The disabilities students especially those who are physically handicapped [3], much less physically active, physically imperfect and also their movement are limited as the researchers' main object [4]. For the disabilities students, researchers observe that speaking English is the difficult skill because they are worried about making mistakes, fearful of criticism, or simply shy [5]. The same problems not also occur to physically normal students but also to the disabilities students namely share the same mother tongue tend to use it because it is easier and because they feel less exposed if they speak their mother tongue [5]. Other typical learner problems in speaking are speaking slowly and taking too long to compose utterances. They also cannot participate actively in conversation, spoken English does not sound natural, had poor grammar and poor pronunciation [6].

Regarding to the descriptions of the problems above, the researchers try to solve the problems by using sociodrama as the suitable method in teaching English speaking to give many opportunities to the disabilities students to practice speaking English with his or her classmates [7]. Sociodrama method is a way of teaching that gives students an opportunity to perform certain roles contained in people's lives [8]. It might be simply defined as a group method in which common or usual experiences are shared in action. As a matter of fact, sociodrama method is commonly used for physically normal students, so it will no doubt if those physically normal students escalate English speaking skill. Because they are physically complete and perfect [9]. Nevertheless, the object of the research is currently dedicated to disabilities students whose physically are not complete and perfect but they have normal brains and sometimes quite better than the normal ones. Based on the curiosity and field observation, the researchers would like to know and explore more about their speaking skill especially in English using sociodrama.

It encourages each of learners to develop self-confidence and self-expression through exploration in activities that explore real life personal feelings and situations [10]. By using sociodrama as a means for exploring issues in the classroom it is possible to celebrate learners' individuality and to create caring and nurturing relationships among teachers and students. Sociodrama teaching method was chosen because this method is expected able to develop potential of language skill which begins with speaking skill [11]. It is able to help the students to improve their speaking skills in a fun way, they can play a role and telling various stories related to social issues such as loves, politics, to social inequality [1].

The novelty of this research is how to apply sociodrama method to escalate disabilities students' English speaking skill. In addition, the researchers would like to analyze whether the application of sociodrama is able to motivate, increase and own their self-confidence in English speaking skill.

\section{Method}

The research used descriptive qualitative method. It was designed to investigate whether sociodrama could be used in the English speaking class for disabilities students and what the effects of sociodrama method would be. The goal of descriptive qualitative studies is a comprehensive summarization, in everyday terms, of specific events experienced by individuals or groups of individuals [12]. Descriptive method is the method which tries to give the explanation about the symptoms relating with the recent situation. It consists of the effort 
of giving the note, the analysis and the interpretation of the recent symptoms which have the characteristics as follows: try to give the fact, straight to the problem and the recent variables are not manipulated by the researcher [13].

To collect the data, the researchers used observation, interview and documentation. The researchers undertook this qualitative study to explore whether students could define themselves not as passive spectators but rather as active participants in role-play and use sociodrama to explore and reflect on matters of personal [14]. The researchers observed 6 (six) disabilities students in grade 8th junior high school mainly focused on orthopedically handicapped. They are from special needs students (Sekolah Luar Biasa) in South Jakarta. The observation took 6 (six) months, starting from March-August 2018. Data analysis taken from every part emphasized on speaking categories vocabulary, fluency, and comprehension during sociodrama.

The researchers use the instrument of assessment to measure the effectiveness of the sociodrama method usage. The instruments are divided into two types, they are pre-test and post-test. Referring from norms referenced evaluation, The criteria for passing this instrument is divided into many criterion, namely : $41-50$ : failed, $51-60$ : fair, $61-70$ : average, $71-$ 80 : good, $81-90$ : fluent, $91-100$ : master [15].

\section{Result And Discussion}

This research started when the researchers visited to the special need school to meet and talk with disabilities students dealing with the researchers' curiosity to know about their English speaking skill. The researchers were given opportunities to join the class during the learning process which was at that time the students were studying about speaking skill in English. There were many disabilities students whom experienced difficulties in speaking their words. The students were shy and less confident to talk. They were afraid of making mistakes and their interests in speaking were a little bit low. When the students were not on their turn to come forward, they looked nervous.

Based on the observation in the grade 8 th of the disabilities students and the information from the teacher, the researchers talk over the problems with the teacher. Regarding to the problem, the researchers use the sociodrama method. Because the researchers observed many sociodrama researches were effective to use this method for physically normal students and the result was good [16]. As eager researchers, they would like to know and prove whether it is possible to use the same method but the objects are the disabilities students especially the orthopedically handicapped. So now, the researchers would like to apply the sociodrama method to the disabilities students.

Once, the sociodrama method was applied to the disabilities students, they felt uncomfortable, afraid of making wrong pronunciation, less confident. Besides that, their bravery did not show up yet and they still did not realize that it is important to have English speaking skill especially through sociodrama method which was still new for them. That is why for the first time their expected achievement was not optimal. It is very important for the disabilities students to have the guidance and motivation in order that they are able to use the sociodrama method well effectively and successfully. Therefore, the researchers conduct some improvements during the learning process.

The researchers divide the components of speaking into many aspects namely vocabulary, fluency and comprehension. Every aspect can be divided into many elements. The elements 
are accuracy of word, understanding each word and word choice. Those elements are categorized as vocabulary aspect, while from fluency aspect can be traced down into intonation, pronunciation and speaking easily. The last aspect is comprehension which can be categorized into understanding the meaning, diction and structure and grammar. The aim of the components division is to be the guidance of the instrument of speaking skill assessment. Each aspect has a maximum score 100. The score is the effectiveness indicator of the speaking skill through sociodrama method. The effectiveness indicator of speaking skill can be analyzed from the students' achievements through the scoring of pre and post - test. The indicator of speaking assessment can be figured out in the table 1.

Table 1. The Indicators of Speaking Skill Assessment

\begin{tabular}{cclc}
\hline No & Assessed Aspects & \multicolumn{1}{c}{ Elements } & Maximum Score \\
\hline 1. & Vocabulary & $\begin{array}{l}\text { Accuracy of Word } \\
\text { Understanding Each Word } \\
\text { Word Choice }\end{array}$ & 100 \\
& \multirow{2}{*}{$\begin{array}{l}\text { Intonation } \\
\text { Fluency }\end{array}$} & $\begin{array}{l}\text { Pronunciation } \\
\text { Speaking easily } \\
\text { Understanding the Meaning } \\
\text { Diction } \\
\text { Structure and Grammar }\end{array}$ & 100 \\
& Comprehension & 100 \\
\hline
\end{tabular}

This research is divided into 2 (two) steps of observation. The first step is giving the pretest. The aim of the pre-test action is to measure the understanding of disabilities students for 3 (three) criterion namely vocabulary, fluency and comprehension before sociodrama method being applied.

Before the researchers conduct this research, the disabilities students were taught by using conventional method which was teacher-centered. This old learning method namely teachercentered makes them feel bored, uncomfortable and unleash their speaking English knowledge. As a result, they still got low competencies in speaking English particularly on the three criterion namely vocabulary, fluency, and comprehension. The assessment was given to students by interviewing them one by one using English, then the researchers gave the score based on their English speaking skill.

The result of the pre-test is visualized on the table 2 below:

Table 2. Pre-Test

\begin{tabular}{cccc}
\hline \multirow{4}{*}{ Respondents } & \multicolumn{3}{c}{ Criterion } \\
\cline { 2 - 4 } & Vocabulary & Fluency & Comprehension \\
\hline Student A & 50 & 44 & 50 \\
Student B & 45 & 56 & 54 \\
Student C & 44 & 34 & 42 \\
Student D & 56 & 52 & 45 \\
Student E & 40 & 43 & 53 \\
Student F & 50 & 55 & 55 \\
Total per Criterion & 47.50 & 47.33 & 49.50 \\
Means Score & & 48.11 & \\
\hline
\end{tabular}

From the table 2, it can be concluded that the lowest score is in fluency element which is 47.33. Besides that, the highest score is in comprehension element which is 49.50 , and the vocabulary element is 47.50 . While the total score of those criterion from disabilities students 
of the grade 8th is still low, about 48.11. The score of 48.11 means that the disabilities students are failed for speaking English. They still need a new method that focused on how to enhance those three criterion. Moreover, the disabilities students need an enjoyable and interesting learning method.

After the researchers gave the pre-test which used conventional method, the second step was the researchers gave the post-test as the final result from the sociodrama method to the six disablities students. The aim of the second step was to measure the effectiveness of using sociodrama method through the post test, the result from the effectiveness of using sociodrama can be seen at the table 3 .

Table 3. . Post-Test

\begin{tabular}{cccc}
\hline \multirow{2}{*}{ Respondents } & \multicolumn{3}{c}{ Table 3. Post-Test } \\
\cline { 2 - 4 } & Vocabulary & Fluency & Comprehension \\
\hline Student A & 70 & 75 & 73 \\
Student B & 73 & 82 & 75 \\
Student C & 81 & 82 & 84 \\
Student D & 76 & 78 & 78 \\
Student E & 68 & 69 & 73 \\
Student F & 74 & 81 & 77 \\
Total per Criterion & 73.66 & 77.83 & 76.66 \\
Means Score & \multicolumn{3}{c}{} \\
\hline
\end{tabular}

From the table 3, it can be analyzed that there is an escalation around 27.94. The number of 27.94 represents of the improvement of speaking English through sociodrama method. The escalation is about the improvement of three criteria namely vocabulary, fluency and comprehension elements. The total means score is 76.05. It derived from vocabulary (73.66), fluency (77.83) and comprehension (76.66) elements. The score of 76.05 means that the disabilities students have good in speaking English criteria. The escalation process could be visualized on the figure 1 .

The score of 76.05 is the proof that the disabilities students especially orthopedically handicapped have the equal skill with the physically normal students. Moreover, the physically limitation does not limit them to pursue their achievement. The sociodrama method makes them feel more confident to explore their ability in language. This thing can be analyzed from the escalation scores from vocabulary, fluency and comprehension scores. This method makes their knowledge of vocabulary risen about 26.16, it is derived from pre-test score and post-test score. The score of 26.16 shows that there is an improvement process of speaking English. In the beginning of the observation process, they were afraid of speaking English because they were lack of vocabulary. While the escalation of fluency of speaking English lies on 30.50 , it means that the disabilities students struggled to strive to make their speaking fluent. Even though, they have limitation and handicapped in their physical features, they finally attained their significant scores. The score of 30.50 is derived from pre-test and post-test result. Hence, the last criteria is comprehension. It elevates about 27.16, it is derived from pre and post-test. It shows that there is a holistic comprehension speaking process from the disabilities students. The escalation of comprehension criteria proves that cognitively the disabilities students' understanding about to comprehend the meaning the words and the sentences, the usage of diction, and the understanding of structure and grammar. From that score, it shows that the physically limitation does not influence the understanding in speaking and communicating in English. 
The sociodrama method encourages their motivation, self- confident, bravery, curiosity and creativity. It also makes the disabilities students enjoy the learning process of speaking English. From the data analysis, the research findings are firstly, this sociodrama method is able to be applied either for physically normal students or disabilities students and the result is effective. Secondly, through the data, it can be inferred that the physically limitation does not make people difficult to reach their achievement, it is proved by the escalation score from pre to post-test process.

The use of sociodrama method has provided the improvement of learning result on students' speaking skills. It is because by using sociodrama teaching method, students directly listened sociodrama speaking by their friends. It made the teaching process was flexible and fun. By implementing sociodrama teaching method, the students tend to listen conversation topics in their daily lives. Besides that, students were also enhancing their perspectives and knowledge about social cases performed by their friends. Therefore, students were getting enthusiastic and motivated to practice their listening skill because the topic was familiar for them. It would give positive impact for the disabilities students especially the orthopedically handicapped ones.

\section{Conclusion}

Based on the data analysis, it can be concluded that the English speaking skill using sociodrama method conducted periodically could escalate the English speaking skill through sociodrama method for disabilities students grade 8th of special need school (Sekolah Luar Biasa), South Jakarta. The escalation of English speaking skill from pre-test 48.11 escalated to 76.05. It was escalated about 27.94.

After implementing the sociodrama method, the classroom conditions became alive, active and fun. The students were more confident to speak English and had more chances to practice with their classmates. There are 2 (two) research findings firstly, this sociodrama method was able to be applied either for physically normal students or disabilities students and the result was effective. Secondly, through the data, it can be inferred that the physically limitation did not make people get difficult to reach their achievement, it was proved by the escalation score from pre to post-test process.

Acknowledgment. This research was supported by Bina Sarana Informatika and Indonesia Nusa Mandiri Foundation. The researchers would like to express the sincere gratitude to Special Need School (Sekolah Luar Biasa) South Jakarta.

\section{References}

[1] S. M. Irwanto, "The Use of Sociodrama Method in Speaking Skill," Slamet Riyadi Univ., pp. 1$18,2017$.

[2] B. M. Nehe, “Using sociodrama in EFL speaking class,” Int. J. Linguist. Lit. Cult., vol. 4, no. 4, pp. 44-52, 2018.

[3] R. Gersten, L. S. Fuchs, J. P. Williams, and S. Baker, "Teaching Reading Comprehension Strategies to Students With Learning Disabilities: A Review of Research,” Rev. Educ. Res., vol. 71, no. 2, pp. 279-320, 2001.

[4] R. Li et al., "Children with physical disabilities at school and home: Physical activity and contextual characteristics,” Int. J. Environ. Res. Public Health, vol. 14, no. 7, 2017. 
[5] B. Gudu, "Teaching Speaking Skills in English Language Using Classroom Activities in Secondary School Level in Eldoret Municipality, Kenya.," J. Educ. Pract., vol. 6, no. 35, pp. 55-63, 2015.

[6] J. C. Richards, "Teaching Speaking Theories and Methodologies," Cambridge english Lang. Teach., pp. 1-32, 2014.

[7] Mencap, "Communicating with people with a learning disability," Voice Learn. Disabil., p. 6, 2014.

[8] N. Ketut and D. Tristiantari, "An Effect Of Sociodrama Method Implementation In Students Language Skill At Fourth Grade Elementary School In Cluster Xii Of Buleleng District,” vol. 1, pp. 45-50, 2017.

[9] A. Shaddock, L. Giorcelli, and S. Smith, Students with disabilities in mainstream classrooms: A resource for teachers. 2007.

[10] R. Sri, Wahyuni and S. S. Fitriani, "THE IMPLEMENTATION OF ROLE PLAY TECHNIQUE IN IMPROVING SPEAKING SKILL," Proc. First Reciprocal Grad. Res. Symp. between Univ. Pendidik. Sultan Idris Syiah Kuala Univ. Febr. 26-28, 2016, Tanjong Malim, Perak, Malaysia, vol. 54, no. 7, pp. 1-7, 2016.

[11] J. junaidimistar hotmail com Mistar and A. atik umamah yahoo com Umamah, "Strategies of learning speaking skill by Indonesian learners of English and their contribution to speaking proficiency," TEFLIN J. A Publ. Teach. Learn. English, vol. 25, no. 2, pp. 203-216, 2014.

[12] V. a. Lambert and C. E. Lambert, "Qualitative Descriptive Research: An Acceptable Design," Pacific Rim Int. J. Nurs. Res., vol. 16, no. 4, pp. 255-256, 2013.

[13] P. Kusumawardhani, "The Analysis Of Conjunctions In Writing An English Narrative Composition : A Syntax Perspective," vol. IX, no. 1, 2017.

[14] D. M. Pecaski McLennan, "Kinder/caring: Exploring the use and effects of sociodrama in a kindergarten classroom," ProQuest Diss. Theses, vol. 2, no. October, p. 291, 2008.

[15] D. MacQuarrie, B. Applegate, and W. Lacefield, "Criterion referenced assessment: Establishing content validity of complex skills related to specific tasks," J. Career Tech. Educ., vol. 24, no. 2, pp. 6-29, 2008.

[16] B. West, "The Effect of Sociodrama Method on Speaking Abilty at the Second Grade SMAN 1 RANAH," pp. 1-4. 